\title{
Kecenderungan Remaja menjadi Pelaku Perundungan-Siber: Kontribusi Harga Diri dan Kesepian
}

\author{
Laras Bethari Ragasukmasuci ${ }^{1} \mathcal{E}$ Maria Goretti Adiyanti ${ }^{2}$ \\ 1,2Fakultas Psikologi Universitas Gadjah Mada
}

\begin{abstract}
This study aimed to empirically test the tendency to be cyber-bullies in adolescents predicted by self-esteem and loneliness. The method used in this study is quantitative method. Research participants were adolescents with an age between 12 - 17 years, using communication devices connected to the internet and claimed to have mocked or insulted other through social network sites. There were 646 participants involved in this study. The data collection in this study used two methods, that were the list of content and scales. The scale used were the scale of tendency of being a cyber-bullies, adolecents self-esteem scale and adolescents loneliness scale. The reseach instrument was analyzed with content validity and realibility of Cronbach alpha $\left(\alpha_{\mathrm{KmPPs}}=0,88, \alpha_{\mathrm{HDR}}=0,90 \alpha_{\mathrm{KR}}=0,88\right)$. Data analysis used multiple regression analysis technique. The results showed that self-esteem and loneliness significantly can predicted the tendency of being a cyber-bullies in adolescents. The tendency to be a cyber-bullies was predicted by self-esteem and loneliness of 3.3\%.
\end{abstract}

Keywords: adolescents; cyberbullying; loneliness; self-esteem

Abstrak. Penelitian ini bertujuan untuk menguji secara empirik kecenderungan menjadi pelaku perundungan-siber pada remaja yang diprediksi oleh harga diri dan kesepian. Metode yang digunakan pada penelitian ini adalah metode kuantitatif. Partisipan penelitian adalah remaja dengan rentang usia antara 12 - 17 tahun, menggunakan piranti komunikasi yang terhubung dengan internet dan menyatakan pernah mengejek dan menghina orang lain melalui situs jejaring sosial. Terdapat 646 partisipan yang terlibat dalam penelitian ini. Pengumpulan data dalam penelitian ini menggunakan dua metode, yaitu daftar isian dan skala. Skala yang digunakan adalah skala kecenderungan menjadi pelaku perundungansiber, skala harga diri remaja, dan skala kesepian remaja. Instrumen penelitian dianalisis dengan validitas isi dan reliabilitas alpha Cronbach $\left(\alpha_{K m P P S}=0,88, \alpha_{\mathrm{HDR}}=0,90 \quad \alpha_{\mathrm{KR}}=0,88\right)$. Analisis data yang digunakan adalah teknik analisis regresi ganda. Hasilnya menunjukkan bahwa harga diri dan kesepian secara signifikan mampu memprediksi kecenderungan menjadi pelaku perundungan-siber pada remaja. Kecenderungan menjadi pelaku perundungan-siber diprediksi oleh harga diri dan kesepian sebesar 3,3\%.

Kata kunci: harga diri; kesepian; perundungan-siber; remaja

Komunikasi dalam jaringan (online) telah menjadi pusat dalam kehidupan seharihari dan interaksi sosial remaja saat ini

${ }^{1}$ Korespondensi mengenai artikel ini dapat dilakukan melalui laras.bethari@ugm.ac.id

ªtau adiyanti_psy@ugm.ac.id
(Sticca \& Perren, 2012; Valkenburg \& Peter, 2011). Penggunaan teknologi komunikasi oleh remaja jauh melebihi orang dewasa, seperti dalam pesan instan dan situs jejaring sosial (Valkenburg \& Peter, 2011). Meluasnya penggunaan teknologi mengakibatkan hubungan 
interpersonal menjadi lebih kompleks karena adanya perubahan dalam bentuk komunikasi dari interaksi tatap muka menjadi interaksi virtual (Brochado, Soares \& Fraga, 2016). Perubahan ini memiliki sisi negatif, seperti melakukan berbagai perilaku kontraproduktif contohnya perundungan-siber (Campbell, 2005; Kowalski, Limber, \& Agatston, 2012; Nixon, 2014). Perundungan-siber adalah bentuk modern dari perundungan (bullying) yang dilakukan dengan menggunakan bentuk media elektronik (Sticca E Perren, 2012), melalui Internet atau telepon seluler (Kowalski, Giumetti, Schroeder, \& Lattaner, 2014). Perundungan-siber sebagai perilaku yang secara tidak langsung sama seperti perundungan namun memiliki perbedaan dalam hal sifat pengulangan dan konten kekerasan psikologis (Ybarra dan Mitchell, 2004), yang dilakukan dengan sengaja melalui internet (William dan Guerra, 2007), dan dilakukan berulang kali dari waktu ke waktu terhadap seorang korban yang tidak bisa mempertahankan diri dengan mudah (Smith, Mahdavi, Carvalho, Russell, \& Tippett, 2008). Misalnya pada situs jejaring sosial Ask.Fm, Instagram dan aplikasi pesan instan LINE ditemukan bentuk-bentuk komentar negatif, kutipan tulisan dalam sebuah linimasa (timeline) yang ditulis remaja yang bertujuan menyindir orang lain, menghina dan mengekspresikan sesuatu menggunakan bahasa daerah yang kasar.

Perkembangan kognitif secara fundamental mengubah cara remaja dalam melihat dirinya sendiri dan lingkungan sekitarnya (Papalia, Old, Feldman, 2008). Hubungan teman sebaya bernilai tinggi selama masa remaja karena merupakan salah satu faktor penting pada perkembangan intimacy (keakraban) dan norma kelompok (Cappadocia, Craig, \& Pepler, 2013). Remaja yang memiliki teman yang terlibat dalam kenakalan dan/atau memiliki sedikit teman yang prososial kemungkinan akan menempatkan remaja pada risiko terlibat dalam perundungan-siber (Calvete, Orue, Estevez, Villardon, \& Padilla, 2010; Li, 2007; Kowalski et al., 2014). Seringnya mengakses media (misalnya internet) kemungkinan menempatkan remaja pada peningkatan risiko terlibat dalam perundungan-siber pada orang lain (Erdur-Baker, 2010; Hinduja \& Patchin, 2008; Makri-Botsari \& Karagianni, 2014; Mishna, Cook, Gadalla, Daciuk, \& Solomon, 2010; Sengupta \& Chaudhuri, 2011; Sticca, Ruggieri, Alsaker, \& Perren, 2013).

Perundungan-siber adalah bentuk agresi elektronik melalui e-mail, panggilan telepon seluler, pesan teks, kontak pesan instan, foto, situs jejaring sosial dan halaman web pribadi (Ortega et al., 2012), website, blog, online video game dan telepon selular penggunaan teknologi informasi dan komunikasi (ICT) (Garaigordobil \& Martinez-Valderrey, 2015). Aktivitas ini ditujukan untuk melakukan pelecehan psikologis pada orang lain atau teman sebaya (Garaigordobil \& MartinezValderrey, 2015).

Kowalski et al., (2014) melakukan penelitian dan meta-analisis untuk mengidentifikasi faktor-faktor yang memengaruhi perundungan-siber dengan menggunakan model agresi umum, hasilnya ditemukan dua faktor yaitu faktor personal dan faktor situasional. Faktor personal kepribadian yaitu harga diri dan kondisi psikologis yaitu kesepian ditemukan berhubungan dengan keterlibatan pada remaja sebagai pelaku perundungan-siber (Atik, 2006; Brewer \& Kerslake, 2015; Patchin \& Hinduja, 2010).

Harga diri dan perundungan-siber

Harga diri adalah evaluasi yang dibuat oleh individu mengenai hal-hal yang 
berkaitan dengan dirinya, yang diekspresikan melalui sesuatu bentuk sikap setuju atau tidak setuju dan menunjukkan tingkat di mana individu itu meyakini dirinya sendiri sebagai individu yang mampu, penting, dan berharga (Coopersmith, 1967). Harga diri merupakan keyakinan individu tentang persepsi akan nilai pribadinya dan dipengaruhi oleh partisipasinya dalam dunia sosial di mana sering terjadi konflik interpersonal (Patchin \& Hinduja, 2010). Beberapa pengalaman mungkin dapat menjadi evaluasi diri positif sehingga membentuk harga diri tinggi, namun ada pula pengalaman yang menghasilkan evaluasi diri negatif yang memungkinkan munculnya harga diri rendah.

Harga diri rendah merupakan dasar dari munculnya beberapa perilaku bermasalah yang dapat berbentuk kekerasan untuk meningkatkan rasa kekuasaan dan kemerdekaan atau sebagai bentuk perilaku mencari perhatian (Ostrowsky, 2010). Penelitian menunjukkan ada hubungan negative antara harga diri dan perundungan (Fanti dan Heinrich, 2015) demikian juga pada 242 remaja sekolah menengah di Malaysia (Uba, Yaacob, Juhari, \& Talib, 2010). Remaja yang terlibat perundungan-siber baik sebagai korban maupun pelaku, memiliki harga diri yang secara signifikan lebih rendah daripada mereka yang tidak terlibat dalam perundungan-siber (Patchin dan Hinduja, 2010).

Pendapat yang berbeda
dikemukakan oleh Baumeister, Bushman \& Campbell (2009), bahwa kekerasan berawal dari harga diri yang tinggi bukan dari harga diri yang rendah. Agresi dan kekerasan paling mungkin terjadi ketika seseorang yang cenderung narsisitik mengalami pembantahan dari orang lain (Baumeister et al., 2009; Bushman \& Baumeister, 1998; dalam Ostrowsky, 2010). Hal ini dikuatkan dengan hasil penelitian Reginasari (2017) dan Guarini, Passini, Melotti dan Brighi (2012). Reginasari (2017) yang menemukan bahwa mayoritas $(82,6 \%)$ partisipan kelompok harga diri tinggi cenderung melakukan perundungan-siber tingkat tinggi. Penelitian Melotti dan Brighi (2012) menemukan, remaja yang menjadi partisipan penelitiannya memiliki tingkat harga diri sedang ke tinggi dan dengan persepsi harga diri yang tinggi di antara teman-teman sebaya dapat meningkatkan risiko menjadi pelaku perundungan-siber. Hal tersebut dilakukan agar remaja dapat mendapatkan pengakuan dari teman sebaya. Kurangnya dukungan sosial teman sebaya diprediksi mempunyai peran pada semua jenis perundungan, termasuk perundungan-siber (Calvete et al., 2010; William dan Guerra, 2007), dan peran dukungan sebaya lebih rendah pada pelaku perundungan-siber (Calvete et al., 2010).

\section{Kesepian dan Perundungan-siber}

Kesepian sebagai salah satu pengalaman tidak menyenangkan dapat terjadi ketika keterlibatan seseorang dalam hubungan sosial secara signifikan berkurang baik kualitas maupun kuantitas (Peplau et al., 1982). Pada masa remaja, kesepian digambarkan ketika remaja merasa ditolak, diasingkan, dikucilkan dan mereka tidak dapat mengendalikan situasi tersebut (Woodward \& Kalyan-Masih, 1990; dalam Rice \& Dolgin, 2008). Ketika kebutuhan akan intimasi meningkat di masa remaja dan memotivasi remaja untuk mencari sahabat (Sullivan dalam Santrock, 2012) namun secara sosial tidak mendapatkannya, muncul perasaan terkucilkan dan ini adalah bentuk kesepian. Ketiadaan sahabat dan jarak hubungan dengan teman sebaya mempunyai kontribusi besar dalam munculnya perasaan kesepian (Rice \& Dolgin, 2008). 
Salah satu cara untuk mendapatkan persahabatan, dukungan emosional atau untuk mencoba menghindari suasana hati negatif adalah dengan berinteraksi dalam jaringan (online) (Larraaga, Yubero, Ovejero, \& Navarro, 2016; Ozgur, Demiralay \& Demiralay, 2014). Di sisi lain, ketika remaja menghabiskan waktu untuk berinteraksi secara online di internet dapat meningkatkan sejumlah risiko potensial negatif (Larraaga et al., 2016; Ozgur, Demiralay \& Demiralay 2014). Risiko menjadi pelaku perundungan-siber meningkat bila remaja merasa kesepian dalam hubungan dengan keluarga dan orang tua (Guarini et al., 2012).

Penelitian ini bertujuan untuk melakukan analisis empirik kecenderungan menjadi pelaku perundungansiber pada remaja yang diprediksi melalui harga diri dan kesepian. Perundunganbaik itu yang dilakukan secara langsung maupun melalui dunia mayamerupakan bentuk masalah remaja yang kompleks karena berhubungan dengan perkembangan psikososialnya (Ybarra, Boyd, Korchmaros, \& Oppenheim, 2012). Dalam suasana pendidikan keluarga di Indonesia yang menekankan pada kehidupan sosial anak, penelitian ini akan memlihat kontribusi harga diri dan kesepian pada responden remaja dalam kaitannya dengan kecenderungan melakukan perundungan-siber Uraian di atas mengarah pada hipotesis: "Harga diri dan kesepian memprediksi kecenderungan menjadi pelaku perundungan-siber pada remaja".

\section{Metode}

\section{Partisipan penelitian}

Partisipan dalam penelitian ini ditentukan berdasarkan beberapa kriteria yakni remaja berusia 12-17 tahun, menggunakan piranti-piranti komunikasi modern seperti smartphone, komputer, laptop atau piranti komunikasi lain yang terkoneksi dengan internet, dan menyatakan pernah mengejek/menghina/meledek orang lain di aplikasi jejaring sosial.

\section{Metode pengumpulan data}

Metode pengumpulan data dalam penelitian ini dilakukan dengan dua jenis metode, yaitu daftar isian dan skala. Daftar isian berisi pertanyaan mengenai status kepemilikan smartphone, kepemilikan komputer/laptop yang terhubung dengan internet di rumah, dan kepemilikan akses internet di luar rumah. Daftar isian ini juga berisi pertanyaan mengenai pilihan aplikasi jejaring sosial yang sering digunakan oleh partisipan penelitian, pilihan durasi aktivitas mengakses aplikasi tersebut dalam satu hari dan pernyataan tentang keterlibatan partisipan penelitian pada perundungansiber.

Skala yang digunakan dalam
penelitian ini terdiri dari skala
kecenderungan menjadi pelaku
perundungan-siber, skala harga diri
remaja dan skala kesepian remaja. Skala kecenderungan menjadi pelaku perundungan-siber dikembangkan berdasarkan aspek-aspek perilaku perundungan-siber yaitu; (1) intensi; (2) repetisi (pengulangan); (3) ketidakseimbangan kekuatan; dan (4) anonimitaspublisitas. Skala kecenderungan menjadi pelaku perundungan-siber memiliki lima pilihan alternatif respons, yaitu hampir selalu; sering; jarang; sesekali; dan tidak pernah. Berdasarkan hasil uji coba alat ukur yang dilakukan pada 96 partisipan uji coba, diperoleh hasil koefisien alpha Cronbach sebesar 0,88 untuk 25 aitem valid. Indeks daya diskriminasi aitem yang ajeg bergerak dari $r_{i x}=0,35$ hingga $r_{i x}=0,62$.

Skala harga diri remaja merupakan bentuk modifikasi dari skala Self-Esteem Inventory milik Coopersmith (1967). Skala 
ini disusun berdasarkan aspek harga diri yang meliputi; success, values, aspiration dan defense. Modifikasi skala dilakukan dengan menyunting kalimat dan menambah jumlah alternatif respons. Skala harga diri remaja memiliki empat pilihan alternatif respons yaitu sangat sesuai, sesuai, tidak sesuai dan sangat tidak sesuai. Berdasarkan hasil uji coba alat ukur yang dilakukan pada 96 partisipan uji coba, diperoleh hasil koefisien alpha Cronbach sebesar 0,896 untuk 27 aitem valid. Indeks daya diskriminasi aitem yang ajeg bergerak dari $r_{i x}=0,306$ hingga $r_{i x}=0,654$.

Skala kesepian remaja dikembangkan berdasarkan tiga aspek kesepian menurut Peplau, Micell, \& Morasch (1982) yang meliputi; kebutuhan akan keintiman (need of intimacy), proses kognitif dan penguatan sosial. Skala kesepian remaja memiliki empat pilihan alternatif respon yaitu sangat sesuai, sesuai, tidak sesuai dan sangat tidak sesuai. Berdasarkan hasil uji coba alat ukur yang dilakukan pada 96 partisipan uji coba, diperoleh koefisien alpha Cronbach sebesar 0,879 untuk 20 aitem valid. Indeks daya diskriminasi aitem yang ajeg bergerak dari $r_{i x}=0,372$ hingga $r_{i x}=0,645$.

\section{Analisis data}

Data dalam penelitian ini dianalisis dengan menggunakan metode analisis regresi berganda. Sebelum memasuki tahap analisis data, terdapat tiga jenis uji asumsi yang dilakukan dalam penelitian ini, yaitu uji normalitas, uji linieritas dan uji multikolinieritas. Di samping itu, kepada beberapa partisipan yang mempunyai kecenderungan tinggi untuk menjadi pelaku perundungan, diberikan beberapa pertanyaan terbuka. Tujuan dari pertanyaan terbuka adalah untuk mengetahui secara lebih mendalam intensi yang mungkin mendasari dilakukannya perundungan-siber.

\section{Hasil}

\section{Deskripsi partisipan penelitian}

Jumlah total partisipan adalah 646 orang yang terdiri dari laki-laki sebanyak 292 orang $(45,2 \%)$ dan perempuan sebanyak 354 orang $(54,7 \%)$. Deskripsi partisipan penelitian yang berusia 12 tahun sebanyak 43 orang $(6,7 \%), 13$ tahun sebanyak 158 orang $(24,5 \%), 14$ tahun sebanyak 129 orang (20\%), 15 tahun sebanyak 110 orang $(17 \%), 16$ tahun sebanyak 146 orang $(22,6 \%)$ dan 17 tahun sebanyak 32 orang (9,3\%). Partisipan penelitian merupakan siswa-siswi dari salah satu SMP Negeri dan SMA Negeri di Kota Bandung. Deskripsi partisipan penelitian yang merupakan siswa kelas 7 sebanyak 103 orang $(15,9 \%)$, siswa kelas 8 sebanyak 228 orang $(35,3 \%)$, siswa kelas 9 sebanyak 4 orang $(0,6 \%)$, siswa kelas 10 sebanyak 184 orang $(28,5 \%)$ dan siswa kelas 11 sebanyak 127 orang (19,5\%). Partisipan yang memiliki durasi penggunaan internet kurang dari 1 jam/hari sebanyak 34 orang (5,3\%), 1-3 jam/hari sebanyak 160 orang (24,8\%), 3-6 jam/hari sebanyak 184 orang (28,5\%), 6-9 jam/hari sebanyak 136 orang $(21,1 \%)$ dan lebih dari 9 jam/hari sebanyak 132 orang $(20,4 \%)$.

\section{Rata-rata hipotetik dan empirik}

Deskripsi data disajikan dalam rerata hipotetik dan rerata empirik. Deskripsi data penelitian dapat dilihat pada Tabel 1.

Skor hipotetik merupakan skor yang diharapkan dicapai oleh partisipan penelitian, sedangkan skor empirik merupakan skor nyata yang diperoleh di lapangan. Kriteria kategorisasi skor didasarkan pada data skor hipotetik. Setelah hasil skor hipotetik dan skor empirik diperoleh, maka hasil tersebut dianalisis untuk mendapatkan jenjang 
Tabel 1.

Deskripsi Data Hipotetik dan Data Empirik

\begin{tabular}{|c|c|c|c|c|c|c|c|c|c|}
\hline \multirow{3}{*}{ Variabel } & \multirow{3}{*}{$N$} & \multicolumn{4}{|c|}{ Data Hipotetik } & \multicolumn{4}{|c|}{ Data Empirik } \\
\hline & & \multirow{2}{*}{ Mean } & \multicolumn{2}{|c|}{ Skor } & \multirow{2}{*}{$S D$} & \multirow{2}{*}{ Mean } & \multicolumn{2}{|c|}{ Skor } & \multirow{2}{*}{$S D$} \\
\hline & & & $\operatorname{Max}$ & Min & & & $\operatorname{Max}$ & Min & \\
\hline KmPP-s* & 646 & 75 & 125 & 25 & 16 & 46,86 & 75 & 30 & 7,56 \\
\hline HDR & 646 & 67,5 & 108 & 27 & 13 & 74,36 & 89 & 51 & 6,02 \\
\hline $\mathrm{KR}$ & 646 & 50 & 80 & 20 & 10 & 40,14 & 57 & 25 & 5,52 \\
\hline
\end{tabular}

* KmPP-s = Kecenderungan menjadi Pelaku Perundungan-siber; HDR = Harga Diri Remaja; KR = Kesepian Remaja

kategorisasi skor. Adapun kriteria kategorisasi, jumlah partisipan dan persentase dalam interpretasi skor kecenderungan menjadi pelaku perundungan-siber, harga diri dan kesepian dapat dilihat pada Tabel 2.

$$
\text { Hasil kategorisasi data }
$$

menunjukkan bahwa mayoritas partisipan penelitian berada pada kategori kecenderungan menjadi pelaku perundungan-siber yang rendah $(93,5 \%)$, memiliki tingkat harga diri sedang $(84,1 \%)$ dan tingkat kesepian yang rendah (52,9\%).

\section{Uji asumsi}

Analisis uji normalitas menggunakan model statistik one sample test dari Kolmogorov-Smirnov (K-SZ). Hasil uji normalitas sebaran data pada variabel kesepian remaja menghasilkan nilai K-SZ sebesar 1,20 $(p>0,05)$. Hasil analisis menunjukkan bahwa ketiga variabel yang digunakan dalam penelitian ini berdistribusi normal.

Uji linearitas menggunakan pendekatan analisis varian. Hasi uji linieritas variabel kecenderungan menjadi pelaku perundungan-siber dan harga diri remaja pada lajur linearity menghasilkan nilai 19,66 $(p<0,05)$ dan lajur deviation from linearity menghasilkan nilai $1,364(\mathrm{p}>0,05)$ yang bermakna bahwa kedua variabel tersebut memiliki hubungan yang linier. Hasi uji linieritas variabel kecenderungan menjadi pelaku perundungan-siber dan kesepian remaja pada lajur linearity menghasilkan nilai 10,02 $(p<0,05)$ dan lajur deviation from linearity menghasilkan nilai

Tabel 2.

Kategorisasi Data

\begin{tabular}{lcccc}
\hline \multicolumn{1}{c}{ Variabel } & Kategorisasi & Rentang Nilai & $N$ & $\%$ \\
\hline Kecenderungan menjadi Pelaku & Rendah & $X<59$ & 604 & $93,5 \%$ \\
Perundungan-siber & Sedang & $59 \leq X<91$ & 42 & $6,5 \%$ \\
& Tinggi & $X>91$ & 0 & 0 \\
Harga diri remaja & Rendah & $X<54,5$ & 1 & $0,2 \%$ \\
& Sedang & $54,5 \leq X<80,5$ & 543 & $84,1 \%$ \\
& Tinggi & $X>80,5$ & 102 & $15,8 \%$ \\
Kesepian Remaja & Rendah & $X<40$ & 342 & $52,9 \%$ \\
& Sedang & $40 \leq X<60$ & 304 & $47,1 \%$ \\
& Tinggi & $X>60$ & 0 & 0 \\
\hline
\end{tabular}

kecenderungan menjadi pelaku perundungan-siber menghasilkan nilai KSZ sebesar 1,22 $(p>0,05)$, pada variabel harga diri remaja menghasilkan nilai K-SZ sebesar $1,08(p>0,05)$, dan pada variabel $1,10(p>0,05)$ yang bermakna bahwa kedua variabel tersebut memiliki hubungan yang linier.

Analisis yang digunakan untuk uji multikolinearitas adalah metode tolerance 
dan value inflation factor (VIF). Hasil uji multikolinearitas menunjukkan bahwa nilai tolerance pada kedua variabel bebas adalah 0,833 (tolerance $>0,10$ ), artinya tidak terjadi multikolinearitas. Sedangkan untuk nilai VIF pada kedua variabel adalah 1,201 (VIF <10), artinya juga tidak terjadi multikolinearitas antara kedua variabel bebas dalam penelitian ini. Maka dapat disimpulkan bahwa variabel harga diri dan kesepian tidak memiliki korelasi sehingga kedua variabel bebas tersebut dapat digunakan sebagai prediktor untuk memprediksi kecenderungan menjadi pelaku perundungan-siber.

\section{Uji hipotesis}

Uji hipotesis dilakukan dengan menggunakan analisis regresi ganda. Hasil analisis regresi menghasilkan nilai $F$ $=11,07(p<0,01)$, artinya bahwa harga diri dan kesepian secara signifikan dapat memprediksi kecenderungan menjadi pelaku perundungan-siber pada remaja. Sumbangan efektif kedua variabel independen terlihat dari besar koefisien $R^{2}$ $=0,03$. Kecenderungan menjadi pelaku perundungan-siber dapat diprediksi secara bersama-sama oleh harga diri dan kesepian sebesar 3,3\%. Hal ini berarti bahwa hipotesis diterima.

\section{Analisis tambahan}

Hasil analisis regresi linier menunjukkan bahwa durasi penggunaan internet memiliki nilai $R^{2}$ sebesar 0,058 dan nilai $F$ sebesar 39,42 $(p<0,01)$. Hal ini bermakna bahwa durasi penggunaan internet berpengaruh secara signifikan pada kecenderungan menjadi pelaku perundungan-siber sebesar 5,8\%. Kontribusi durasi penggunaan internet pada kecenderungan menjadi pelaku perundungan-siber sebesar 0,366 (36,6\%) dan memiliki arah yang positif. Hal ini bermakna bahwa semakin tinggi durasi penggunaan internet dalam mengakses aplikasi jejaring sosial maka akan semakin tinggi kecenderungan menjadi pelaku perundungan-siber pada remaja dan sebaliknya. Remaja perempuan ditemukan menggunakan internet dengan durasi lebih lama dibandingkan dengan remaja laki-laki. Berdasarkan analisis dengan metode oneway ANOVA, diperoleh hasil bahwa terdapat perbedaan signifikan antara kecenderungan menjadi pelaku perundungan-siber pada remaja. Remaja usia 16 tahun memiliki kecenderungan menjadi pelaku perundungan-siber lebih tinggi dibandingkan dengan remaja usia 13, 14 dan 15 tahun. Ditemukan pula bahwa remaja kelas 11 memiliki kecenderungan menjadi pelaku perundungan-siber lebih tinggi dibandingkan dengan remaja kelas 7, 8, dan 10 .

\section{Diskusi}

Penelitian ini bertujuan untuk menguji secara empirik kecenderungan menjadi pelaku perundungan-siber pada remaja yang diprediksi melalui harga diri dan kesepian. Pengujian hipotesis menunjukkan bahwa harga diri dan kesepian bersama-sama secara signifikan dapat memprediksi kecenderungan menjadi pelaku perundungan-siber pada remaja. Temuan ini mendukung hasil temuan sebelumnya yang dilakukan oleh Atik (2006) yang melaporkan bahwa harga diri dan kesepian ditemukan sebagai prediktor umum pada remaja yang menjadi pelaku dan korban perundungan. Temuan penelitian ini juga sejalan dengan hasil penelitian Brewer dan Kerslake (2015) yang menemukan bahwa harga diri, empati dan kesepian secara bersamasama memprediksi kejadian perundungan-siber pada pelaku dan korban.

Brighi et al. (2012) menyatakan bahwa tindakan perundungan berkaitan 
dengan harga diri dan perasaan kesepian karena kesulitan berteman (pada remaja laki-laki) dan diabaikan atau dikucilkan oleh orang lain (pada remaja perempuan). Harga diri dan kesepian merupakan faktor personal yang penting dalam perkembangan remaja. Brewer dan Kerslake (2015) menjelaskan bahwa adanya penurunan tingkat harga diri dapat meningkatkan kecenderungan menjadi pelaku perundungan-siber pada remaja. Guarini Passini, Melotti dan Brighi, (2012) juga menemukan bahwa risiko menjadi pelaku perundungan-siber akan meningkat bila remaja merasa kesepian. Transisi dari masa kanak-kanak ke masa remaja ditandai dengan kebutuhan untuk membangun sebuah identitas yang mengutamakan otonomi dan kemerdekaan dari orangtua (Santrock, 2003). Transisi tersebut juga mengarah pada perubahan yang mendadak dalam struktur dan organisasi kelompok sebaya para remaja.

Krisis identitas pada masa remaja menghasilkan pengembangan sense of self dalam kaitannya dengan orang lain dan pemikiran internal tentang dirinya sendiri dan segala keinginannya (Steinberg, 2011). Dalam periode moraturium psikososial ini, remaja berusaha menanggapi dan mengidentifikasi perbedaan permintaan antara orangtua dan teman sebayanya (Santrock, 2012; Brighi et al., 2012). Remaja berjuang untuk memisahkan nilai dan kepercayaan orang lain dari nilai-nilai dan keyakinan mereka sendiri. Hal itu membuat mereka mungkin tidak hanya merasa terisolasi dari orang lain tetapi juga terpisah dari berbagai aspek dirinya (Sippola \& Bukowski, 1999). Sullivan (1953; dalam Sippola \& Bukowksi, 1999) mengemukakan bahwa pertemanan berkontribusi pada perkembangan remaja dengan memberi kesempatan pada remaja untuk "melihat diri sendiri melalui mata orang lain". Hal ini berguna tidak hanya untuk membantu remaja mengklarifikasi perasaan diri, tetapi juga memberi kesempatan remaja untuk dapat menjelaskan dengan tepat bagaimana sesuatu serupa dan/atau berbeda dari orang lain (Sippola \& Bukowksi, 1999). Bagaimanapun juga, tugas perkembangan ini bukan sesuatu yang mudah dicapai bagi setiap remaja.

Kurangnya keakraban dan hubungan teman sebaya yang bermakna akan mengakibatkan munculnya perasaan kesepian (Baumeister \& Leary, 1995), dan kesulitan untuk membangun sense of self yang kuat akan berhubungan dengan rendahnya harga diri remaja (Marcia, Waterman, Matterson, Archer, \& Orlosky, 1993; dalam Vanhalst, Luyckx, Scholte, Engels, \& Goossens, 2013). Remaja berperilaku transgressive untuk mengkomunikasikan sesuatu tentang diri mereka kepada publik. Tindakan menyimpang diadopsi remaja agar dapat membangun dan mempertahankan reputasi tertentu dalam konteks sosial di mana ia berinteraksi dan hal itu mencerminkan orientasinya menuju otoritas formal. Melanggar peraturan sosial menjadi cara untuk mengelola reputasi remaja dalam kelompok yang secara kolektif mendukung norma perilaku antisosial semacam itu (Brighi et al., 2012).

Patchin dan Hinduja (2010) menemukan bahwa remaja yang terlibat dalam perundungan-siber, baik sebagai korban dan pelaku, memiliki harga diri yang secara signifikan lebih rendah daripada mereka yang tidak terlibat dalam perundungan-siber. Brewer dan Kerslake (2015) juga menjelaskan bahwa adanya penurunan tingkat harga diri dapat meningkatkan kecenderungan menjadi pelaku perundungan-siber pada remaja. Berbeda dengan temuan tersebut, Reginasari (2017) menemukan bahwa mayoritas partisipan kelompok harga diri 
tinggi cenderung melakukan perundungan-siber tingkat tinggi. Brighi et al. (2012) menemukan bahwa remaja yang menjadi partisipan penelitiannya memiliki harga diri tingkat sedang ditemukan dapat meningkatkan risiko menjadi pelaku perundungan-siber. Hal tersebut dilakukan agar remaja dapat mendapatkan pengakuan dari teman sebaya karena telah melakukan perundungan-siber. Berdasarkan hasil analisis kategorisasi, mayoritas partisipan dalam penelitian ini memiliki harga diri tingkat sedang. Coopersmith (1967) menjelaskan bahwa seseorang dengan harga diri tingkat sedang berada di antara penilaian dan pengalaman. Mereka memiliki sejumlah pernyataan diri yang positif tetapi lebih moderat dalam penilaian kompetensi, signifikasi dan harapannya.

Kebutuhan untuk memiliki teman akrab menjadi sangat penting selama masa remaja (Rice \& Dolgin, 2008). Masa remaja sangat rentan terhadap perasaan kesepian karena mereka cenderung menyadari perbedaan terbesar antara pencarian terhadap keakraban dan kegagalan untuk memuaskannya (Rubenstein, Shaver dan Peplau, 1979; dalam Chen, 2003). Remaja mungkin tidak lebih kesepian dibandingkan orang-orang di titik transisi masa peralihan yang lain dalam kehidupannya, namun sifat unik dan tugas perkembangan di mana remaja terlibat, membuat pengalaman kesepian menjadi berbeda. Kesepian mengekspresikan ketidakpuasan atas hubungan untuk memiliki hubungan yang akrab dengan teman yang baik dan dekat dan/atau sebuah bentuk reaksi atas pengucilan atau penolakan oleh kelompok sosial yang diinginkan (Parker \& Asher, 1993). Remaja yang tidak memiliki sahabat dan merasa jauh dari hubungan sebaya yang lebih besar dapat berkontribusi pada perasaan remaja yang kesepian (Hoza, Bukowski, \& Beery, 2000; dalam Rice \& Dolgin, 2008). Hal tersebut menjadi dasar mengapa penelitian ini bertujuan untuk menguji secara empirik kesepian sebagai prediktor kecenderungan menjadi pelaku perundungan-siber pada remaja. Karena persepsi kuantitas dan kualitas hubungan sosial yang tersedia dalam kehidupan sehari-hari dapat memengaruhi keinginan untuk terlibat dalam interaksi sosial dalam jaringan (online) (Brewer \& Kerslake, 2015). Remaja yang merasa kesepian akan mencari persahabatan, dukungan emosional atau untuk mencoba menghindari suasana hati yang negatif dengan berinteraksi dalam jaringan (online), namun dengan menghabiskan waktu untuk berinteraksi di Internet dapat meningkatkan sejumlah risiko potensial (Larraaga et al., 2016), seperti terlibat dalam bentuk-bentuk perundungan-siber (Guarini, Passini, Melotti, \& Brighi, 2012). Teman sebaya merupakan model yang efektif untuk menguatkan pendekatan perilaku yang tepat pada remaja secara sosial. Menghabiskan waktu dengan teman akan memberikan remaja keuntungan unik, dan istimewa untuk mengekspresikan dan memahami perasaannya (Lord, 1999; dalam Margalit, 2010). Adanya dukungan teman sebaya juga berhubungan dengan penurunan kemungkinan keterlibatan dalam perundungan baik secara fisik maupun dalam perundungan-siber (William \& Guerra, 2007).

$$
\text { Hasil kategorisasi data }
$$

kecenderungan menjadi pelaku perundungan-siber pada partisipan penelitian yang menunjukkan bahwa mayoritas partisipan penelitian berada pada tingkat kecenderungan menjadi pelaku perundungan-siber yang rendah. Gambaran hasil kategorisasi kecenderungan ini belum tentu bermakna bahwa partisipan penelitian sama sekali 
tidak pernah terlibat dalam perilaku perundungan-siber. Pandangan ini didasarkan pada pernyataan partisipan yang menyatakan pernah mengejek atau menghina orang lain meskipun hanya bercanda melalui aplikasi jejaring sosial sebagai bentuk indikasi keterlibatan menjadi pelaku perundungan-siber. Mengacu pada pendapat Hinduja \& Patchin (dalam Brush \& Halley, 2014) yang membagi perilaku perundungansiber menjadi tiga tingkat kategori, yaitu ringan, sedang, dan berat, maka mayoritas partisipan penelitian ini termasuk ke dalam kelompok dengan kecenderungan perilaku perundungan-siber ringan yang diidentifikasi dengan adanya perilaku menggoda teman sebaya sebagai bentuk hiburan, pengabaian atau pengucilan (exclusion), pemanggilan nama (labelling), mengejek atau menghina (harrasment) dan mengirim pesan marah, kasar atau cabul (flamming).

Berdasarkan hasil analisis pertanyaan terbuka tentang pengalaman perundungan-siber partisipan penelitian dalam alat ukur, ditemukan beberapa pernyataan yang mengarah pada motivasi remaja melakukan perundungan-siber sebagai bentuk hiburan.

"Saya pernah membully di media sosial, tapi maksud saya hanya bercanda" (perempuan, 13 tahun).

"Saya pernah melakukan cyberbullying tapi maksud saya cuma bercanda bukan serius" (perempuan, 14 tahun).

"Saya pernah mem-bully dan dibully teman-teman tetapi itu hanya sekedar bercanda" (perempuan, 13 tahun).

"Mungkin kalau melakukan bully di medsos secara habis-habisan tidak pernah, tapi jika hanya mengejek teman dengan candaan yang tanpa sadar menyakitinya pernah saya lakukan" (perempuan, 15 tahun).

"Saya pernah di-bully di medsos, rasanya tidak enak, tapi karena hanya bercanda, saya anggap angin lalu saja..." (laki-laki, 16 tahun).

Kenyataan ini kemudian diterima sebagai suatu hal yang wajar oleh korban bahwa pelaku melakukan hal itu dengan tujuan sebagai sebuah hiburan atau sekedar untuk bersenang-senang. Temuan ini sejalan dengan temuan penelitian sebelumnya yang menyatakan bahwa motif remaja melakukan perundungansiber bukan sengaja untuk menyakiti, namun hanya untuk iseng atau bercanda dengan teman-temannya (Brewer \& Kerslake, 2015; Pandori, 2013; Yuliawanti, 2017). Martin, Puhlik-Doris, Larsen, Gray \& Weir (2003; dalam Sari, 2015) mengembangkan model mengenai rasa humor sebagai ciri kepribadian multidimensi. Menurut model ini, humor memiliki dua aspek yaitu aspek adaptif dan maladaptif. Humor adaptif terbagi menjadi dua, yaitu sebagai afiliasi dan pengembangan diri. Sedangkan, humor maladaptif terdiri dari humor self-defeating dan humor agresif. Terkait dengan gaya humor tersebut, hasil penelitian Erickson dan Feldstein (2007) menemukan bahwa gaya humor afiliasi dan self-defeating secara signifikan digunakan remaja dalam upaya untuk meningkatkan hubungan interpersonal dengan teman sebaya. Gaya humor yang digunakan dapat memengaruhi hubungan sosial remaja karena gaya humor yang berbeda lebih mudah diterima oleh orang lain (Fox, Hunter, \& Jones, 2016).

Anonimitas dalam perundungansiber membuat seseorang mudah untuk mengatakan dan melakukan hal-hal yang 
tidak mungkin dilakukan secara langsung, serta orang-orang kadang terjebak dalam perundungan-siber tanpa sengaja (Reece, 2012), misalnya seseorang yang membuat lelucon tentang orang lain karena ia merasa bosan terhadap sesuatu dan merasa hal tersebut merupakan hal yang menyenangkan. Oleh karena itu, bagi remaja, dunia maya secara antusias diadopsi karena mewakili 'ruang' mereka, terlihat oleh kelompok sebaya merupakan kesempatan yang menarik namun relatif aman untuk membangun, bereksperimen dan menyajikan sebuah proyek refleksi diri dalam konteks sosial (Buchner, BoisReymond \& Kruger, 1995; dalam Livingstone, 2008). Aspek ini pada akhirnya dapat menimbulkan efek disinhibisi online dan disasosiasi identitas pada seseorang (Suler, 2004). Remaja merasa tidak terikat aturan yang pada akhirnya membuat mereka kurang terkendali dan mengekspresikan diri secara lebih terbuka. Hal tersebut yang menimbulkan diasosiasi identitas, karena remaja memiliki kesempatan untuk memisahkan tindakan secara online dari gaya hidup dan identitasnya dalam kehidupan nyata. Dalam proses disasosiasi identitas, remaja tidak harus berperilaku dengan mengakui hal itu dalam konteks penuh dari identitas offlinenya sehingga remaja dapat membangun identitas online dan offline-nya secara terpisah (Suler, 2004). Pada perilaku perundungan-siber, remaja dapat mengalihkan tanggung jawab atas perilaku tersebut dan bahkan bisa meyakinkan dirinya sendiri bahwa bukan mereka yang melakukannya.

Kecenderungan untuk menjadi pelaku perundungan-siber bisa semakin meningkat tatkala remaja tak memiliki standar moral dalam proses regulasi diri. Standar moral yang digunakan individu dalam proses regulasi diri dimaksudkan untuk mengevaluasi konsekuensi potensial dari perilaku yang dimaksudkan untuk diri mereka sendiri. Jika melanggar moral, standar penghukuman diri (yaitu rasa bersalah) mereka diantisipasi, hal tersebut merupakan perilaku yang tidak disadari. Namun, ada kemungkinan bagi seseorang untuk berperilaku yang tidak sesuai dengan standar moral mereka tanpa merasa bersalah (Bandura, 2001). Perilaku perundungan-siber yang dilakukan remaja juga terkait dengan egosentrisme yang muncul pada masa remaja sebagai akibat dari kegagalan diferensiasi antara hal subjektif dan objektif yang memunculkan karakteristik personal fable (Inhelder \& Piaget, 1955; dalam Galanaki, 2012). Elkind (1967; dalam Alberts, Elkind, Ginsberg, 2007) mengemukakan bahwa personal fable menimbulkan rasa kebal pada remaja dan berhubungan dengan kecenderungan melakukan perilaku yang berisiko. Krcmar (2012; dalam Cingel, Krcmar, Olsen, 2015) menyatakan bahwa personal fable berkaitan dengan perundungan-siber karena remaja memiliki cara berpikir dan keyakinan yang tinggi bahwa mereka sangat kuat dan lebih penting dibandingkan dengan orang lain, sekaligus percaya bahwa mereka tidak akan tertangkap karena melakukan perundungan-siber.

Interaksi dalam jaringan (online) sangat menyenangkan bagi remaja karena dapat melakukan perilaku seperti saling menggoda, menyindir dan menertawakan remaja lain (Livingstone, 2008). Motif bercanda atau humor menjadi motif yang paling umum dalam perilaku perundungan-siber, karena berawal dari bercanda dengan teman lalu berkembang menjadi tipe-tipe perilaku perundungansiber yang lain (Yuliawanti, 2017). Tipetipe perilaku perundungan-siber lain yang dilakukan remaja yang ditemukan dalam penelitian ini antara lain; (1) flamming yaitu mengirim pesan marah, kasar atau 
cabul yang diarahkan pada seseorang (Hinduja \& Patchin, 2014); (2) harassment adalah tindakan yang dimaksudkan untuk mengganggu atau melecehkan orang lain (Hinduja \& Patchin, 2014); (3) denigration yaitu dengan memasang atau mengirim foto seseorang dengan merubah bentuknya (Kowalski et al., 2012); (4) impersonation yaitu peniruan dilakukan pelaku dengan cara bertindak sebagai korban (Kowalski et al., 2012); (5) outing yaitu berbagi informasi pribadi, informasi tersebut sering kali memalukan dan tidak pernah dimaksudkan untuk dibagikan pada orang-orang (Kowalski et al., 2012); dan (6) exclusion yaitu dengan sengaja tidak memasukkan seseorang dalam sebuah kelompok di dunia maya, seperti daftar teman atau permainan.

Internet telah menjadi platform baru dalam interaksi sosial remaja dengan teman sebayanya (Ang, 2015), karena hal tersebut memberikan mereka kesempatan untuk tetap terhubung dengan temantemannya meskipun tidak saling bertemu (Weber \& Pelfrey, 2014). Namun, interaksi online yang terlalu sering dianggap sebagai faktor risiko munculnya perilaku perundungan-siber (Sticca et al., 2013). Peneliti sepakat bahwa adanya peningkatan waktu dalam menggunakan internet berhubungan dengan meningkatnya keterlibatan dalam perundungan-siber (Festl, Scharkow, \& Quandt, 2013). Secara umum, mayoritas partisipan penelitian menggunakan internet untuk mengakses aplikasi jejaring sosial selama 3-6 jam dalam sehari. Tidak hanya berkaitan dengan durasi waktu, Den Hamer dan Konijn (2015) juga mengemukakan bahwa tingginya paparan media yang berisi perilaku anti-sosial dan perilaku berisiko di Internet secara signifikan memberikan kontribusi yang lebih tinggi pada munculnya perundungan-siber, adanya peningkatan paparan konten media juga secara signifikan berhubungan dengan peningkatan perundungan-siber dari waktu ke waktu. Durasi penggunaan internet dalam penelitian ini ditemukan berpengaruh signifikan terhadap kecenderungan menjadi pelaku perundungan-siber dan memiliki arah hubungan yang positif. Artinya, semakin tinggi durasi penggunaan internet dalam mengakses aplikasi jejaring sosial maka semakin tinggi tingkat kecenderungan menjadi pelaku perundungan-siber. Temuan ini mendukung hasil penelitian terdahulu yang menemukan bahwa semakin lama remaja terpapar internet maka risiko keterlibatan pada perundungan-siber akan semakin tinggi baik sebagai pelaku maupun sebagai korban (Erdur-Baker, 2010; Hinduja \& Patchin, 2008; Kowalski, Giumetti, Schroeder, \& Lattaner, 2014; Sengupta \& Chaudhuri, 2011; Walrave \& Heiman, 2011; Ybarra \& Mitchell, 2004). Remaja perempuan ditemukan menggunakan internet dengan durasi lebih lama dibandingkan dengan remaja laki-laki.

Temuan lain dalam penelitian ini menunjukkan bahwa remaja usia 16 tahun ditemukan memiliki kecenderungan menjadi pelaku perundungan-siber lebih tinggi dibandingkan dengan remaja usia 13, 14 dan 15 tahun. Sejalan dengan hal tersebut, ditemukan pula bahwa remaja kelas 11 memiliki kecenderungan menjadi pelaku perundungan-siber lebih tinggi dibandingkan dengan remaja kelas 7, 8, dan 10. Perubahan fundamental remaja bersifat universal, sehingga efeknya bergantung pada konteks di mana hal itu terjadi. Perbedaan yang terjadi dalam perkembangan remaja dipengaruhi langsung oleh konteks di mana remaja berkembang, termasuk masyarakat, budaya dan zaman di mana ia tumbuh (Steinberg, 2011). Perundungan-baik itu yang dilakukan secara langsung maupun melalui dunia maya-merupakan bentuk 
masalah remaja yang kompleks karena berhubungan dengan perkembangan psikososialnya (Ybarra et al., 2012). Transisi perkembangan dari masa pubertas (remaja awal) ke masa remaja akhir, memberikan perbedaan pada hubungan teman sebaya pada remaja. Pengaruh teman sebaya mencapai puncaknya pada awal masa remaja, biasanya usia 12 dan 13 tahun lalu kemudian menurun pada masa remaja pertengahan dan akhir (Papalia et al., 2008). Persepsi remaja bahwa temanteman sebaya mereka dapat dipercaya, saling peduli dan membantu secara signifikan akan menurunkan angka perundungan verbal, fisik dan siber (William \& Guerra, 2007). Sedangkan remaja yang memiliki teman yang terlibat dalam kenakalan dan/atau memiliki sedikit teman yang prososial kemungkinan akan menempatkan remaja pada risiko terlibat dalam perundungansiber (Calvete et al., 2010; Li, 2007; Kowalski et al., 2014).

\section{Kesimpulan}

Berdasarkan hasil penelitian maka dapat disimpulkan bahwa kecenderungan menjadi pelaku perundungan-siber dapat diprediksi oleh harga diri dan kesepian remaja. Kedua prediktor tersebut bersama-sama mampu memprediksi kecenderungan menjadi pelaku perundungan-siber pada remaja secara signifikan. Dalam penelitian ini juga ditemukan bahwa durasi penggunaan internet dalam mengakses media sosial mampu memprediksi kecenderungan menjadi pelaku perundungan-siber secara signifikan, dimana semakin tinggi durasi penggunaan internet dalam mengakses media sosial pada remaja maka akan semakin tinggi kecenderungan menjadi pelaku perundungan-siber. Remaja perempuan ditemukan menggunakan internet dengan durasi lebih lama dibandingkan dengan remaja laki-laki.

Saran

Berdasarkan hasil penelitian, maka saran yang dapat diberikan bagi remaja diharapkan dapat lebih meningkatkan peran dalam menggali kemampuan, kesadaran dan kepekaan diri tentang nilai dan situasi lingkungan di sekitarnya sehingga dapat mengevaluasi respons yang diterima saat berhubungan dengan orang lain dengan positif. Remaja diharapkan dapat mengutamakan etika dalam berinteraksi dengan orang lain baik secara langsung maupun dengan menggunakan teknologi tertentu.

\section{Kepustakaan}

Alberts, A., Elkind, D., \& Ginsberg, S. (2007). The personal fable and risktaking in early adolescence. Journal of Youth Adolescence, 36, 71-76. doi: 10.1007/s10964-006-9144-4

Ang, R. P. (2015). Adolescent cyberbullying: A review of characteristics, prevention and intervention strategies. Aggression and Violent Behavior, 25(A), 35-42. doi: 10.1016/j.avb.2015.07.011

Atik, G. (2006). The role of locus of control, self-esteem, parenting style, loneliness and academic achievement in predicting bullying among middle school students (Tesis tidak dipublikasikan). Middle East Technical University, Ankara.

Bandura, A. (2001). Social cognitive theory: An agentic perspective. Annual Review Psychology, 52, 1-26. doi: $10.1146 /$ annurev.psych.52.1.1

Baumeister, R. F., Bushman, B. J., Campbell, W. K. (2000). Self-Esteem, narcissism, and aggression does violence result from low self-esteem or from threatened egotism?. Current Directions in Psychological 
Science, $\quad 9(1), \quad 26-29 . \quad$ doi: $\underline{10.1111 / 1467-8721.00053}$

Baumeister, R. F., \& Leary, M. R. (1995). The need to belong: Desire for interpersonal attachments as a fundamental human motivation. Psychological Bulletin, 117(3), 497-529. doi: 10.1037/0033-2909.117.3.497

Brewer, G. \& Kerslake, J. (2015). Cyberbullying, self-esteem, empathy, and loneliness. Journal of Computers in Human Behavior, 48, 255-260.

doi: 10.1016/j.chb.2015.01.073

Brighi, A., Melotti, G., Guarini, A., Genta, M. L., Ortega, R., Mora-Merchán, J., . . . Thompson, F. (2012). Self-esteem and loneliness in relation to cyberbullying in three European countries. In Q. Li, D. Cross, \& P. K. Smith (Eds.), Cyberbullying in the global playground: Research from international perspectives (pp. 32-56). : Wiley-Blackwell.

Brochado, S., Soares, S., \& Fraga, S. (2016). A scoping review on studies of cyberbullying prevalence among adolescents. Trauma, Violence, $\mathcal{E}$ Abuse, 18(5), 523-531. doi: $10.1177 / 154838016641668$

Brush, S. R. G., \& Halley, H. (2014). Cyberbullying:

Characteristics, administrators' responsibilities, and effective communication strategies (Disertasi tidak dipublikasikan). Saint Louis University, St. Louis. Diakses melalui https://search.proquest.com/docvie $\mathrm{w} / 1564765832$ ?pq-origsite $=$ gscholar.

Calvete, E., Orue, I., Estevez, A., Villardon, L., \& Padilla, P. (2010). Cyberbullying in adolescents: Modalities and aggressors' profile. Computers in Human Behavior, 26, 1128-1135.

doi: $\underline{10.1016 / j . c h b .2010 .03 .017}$
Campbell, M. A. (2005). Cyber bullying: An old problem in a new guise? Autralian Journal of Guidance and Counselling, 15(1), 68-76. doi: 10.1375.ajgc.15.168

Cappadocia, M. C., Craig, W. M., \& Pepler, D. (2013). Cyberbullying: Prevalence, stability and risk factors during adolescence. Canadian Journal of School Psychology, 28(2), 171-192. doi: $10.1177 / 0829573513491212$

Chen, W. (2003). Adolescents interpersonal relatioship quantity and quality, belongingness and loneliness. (Disertasi tidak dipublikasikan). National Chengchi University, Taipei.

Cingel, D. P., Krcmar, M., \& Olsen, M. K. (2015). Exploring predictors and consequences of personal fable ideation on Facebook. Computers in Human Behavior, 48, 28-35. doi: 10.1016/j.chb.2015.01.017

Coopersmith, S. (1967). The antecedents of self-esteem. W. H. Freeman and Company : San Fransisco.

Den Hamer, A. H., \& Konijn, E. A. (2015). Adolescents' media exposure may increase their cyberbullying behavior: A longitudinal study. Journal of Adolescent Health, 56, 203208.

doi: 10.1016.j.jadohealth.2014.09.016

Erdur-Baker, O. (2010). Cyberbullying and its correlation to traditional bullying, gender, and frequent, and risky usage of internet-mediated communication tools. New Media Society, 12(1), 109-125. doi: 10.1177/1461444809341260

Erickson, S. J., \& Feldstein, S. W. (2007). Adolescents humor and its relationship to coping, defense strategies, psychological distress and well-being. Child Psychiatry and Human Development, 37, 255-271. doi: 10.1007/s10578-006-0034-5 
Fanti, K. A., \& Heinrich, C. C. (2015). Effects of self-esteem and narcissism on bullying and victimization during early adolescence. Journal of Early Adolescence, 35(1), 5-29. doi: $\underline{10.1177 / 0272431613519498}$

Festl, R., Scharkow, A., \& Quandt, T. (2013). Peer influence, internet use and cyberbullying comparison of different context effect among German adolescents. Journal of Children and Media, 7(4), 446-462. doi: 10.1080/14782798.2013.78514

Fox, C. L., Hunter, S. C., \& Jones, S. E. (2016). Longitudinal associations between humor styles and psychosocial adjustment in adolescence. Europe's Journal of Psychology, 12(3), 377-389. doi: 10.5964/ejop.v12i3.1065

Galanaki, E. P. (2012). The imaginary audience and the personal fable: A test of Elkind's theory of adolescent egocentrism. Psychology, 3(6), 457466. doi: $10.4236 /$ psych.2012.36065

Garaigordobil, M., \& Martinez-Valderrey, V. (2015). Effects of cyberprogram 2.0 on "face-to-face" bullying, cyberbullying, and empathy. Psicothema, 27(1), 4551. doi: 10.7334/psicothema2014.78

Guarini, A., Passini, S., Melotti, G., \& Brighi, A. (2012). Risk and protective factors on perpetration of bullying and cyberbullying. Studia Edukacyjne NR, 23, 33-55.

Hinduja, S., \& Patchin, J. W. (2008). Cyberbullying: An explanatory analysis of factor related to offending and victimization. Deviant Behavior, 29(2), 129-156. doi: 10.1080/01639620701457816

Hinduja, S. \& Patchin, J. W. (2014). Cyberbullying glossary, brief overview of common terms. Diakses melalui Cyberbullying Research Center www.cyberbullying.us (pada 20 Januari 2016).

Kowalski, R. M, Limber, S. P., \& Agatston, P. W. (2012). Cyber bullying, bullying in the digital age (Edisi kedua). Blackwell Publishing : USA.

Kowalski, R. M., Giumetti, G. W., Schroeder, A. N., \& Lattanner, M. R. (2014). Bullying in the digital age: A critical review and meta-analysis of cyberbullying research among youth. Psychological Bulletin, 140(4), 1073-1137. doi: $\underline{10.1037 / a 0035618}$

Larraaga, E., Yubero, S., Ovejero, A., \& Navarro, R. (2016). Loneliness, parent-child communication and cyberbullying victimization among Spanish youth. Computers in Human Behavior, 65, 1-8. doi: 10.1016/j.chb.2016.08.015

Li, Q. (2007). New bottle but old wine: A research of cyberbullying in school. Computers in Human Behavior, 23(4), 1777-1791. doi: 10.1016/j.chb.2005.10.005

Livingstone, S. (2008). Taking risky opportunities in youthful content creation: teenagers' use of social networking sites for intimacy, privacy, and self-expression. New Media E Society, 10(3), 393-411. doi: $\underline{10.1177 / 1461444808086415}$

Makri-Botsari, E., \& Karagianni, G. (2014). Cyberbullying in greek adolescents: The role of parents. Procedia - Social and Behavioral Science, 116, 32413253.

doi: 10.1016/j.sbspro.2014.01.742

Margalit, M. (2010). Lonely children and adolescents, self-perceptions, social exclusion and hope. Springer Science+Business Media : London.

Mishna, F., Cook, C., Gadalla, T., Daciuk, J., \& Solomon, S. (2010). Cyber bullying behaviors among middle and high school students. American Journal of Ortopsychiatry, 80(3), 362- 
374. doi: $\quad$ 10.1111/j.19390025.2010.01040.x

Nixon, C. L. (2014). Current perspective: the impact of cyberbullying on adolescent health. Adolescent Health, Medicine and Therapeutics, 5, 143-158. doi: 10.2147/AHMT.S36456

Ortega, F. B, Lee, D. C, Katzmarzyk, P. T., Ruiz, J. R., Sui, X., Church, T. S., \& Blair, S. N. (2012). The intriguing metabolically healthy but obese phenotype: cardiovascular prognosis and role of fitness, Eur Heart J. 34(5), 389-97. doi: 10.1093/eurheartj/ehs174.

Ostrowsky, M. K. (2010). Are violent people more likely to have low selfesteem or high self-esteem? Agression and Violent Behavior, 15, 6975. doi: 10.1016/j.avb.2009.08.004

Ozgur, H., Demiralay, T. \& Demiralay, I. (2014). Exploration of problematic internet use and loneliness among distance education students. Turkish Online Journal of Distance Education, 15(2), 75-90.

Pandori, J. K. (2013). Adolescents perceptions of victims and perpetrators of cyberbullying (Tesis tidak dipublikasikan). Western University, London, Canada.

Papalia, D. E., Old, S. W., \& Feldman, R. D. (2008). Human development (Psikologi perkembangan). Diterjemahkan oleh: A.K. Anwar. Jakarta : Kencana.

Parker, J. G., \& Asher, S. R. (1993). Friendship and friendship quality in middle childhood: Links with peer group acceptance and feelings of loneliness and social dissatisfaction. Developmental Psychology, 29(4), 611621. doi: $10.1037 / 0012-1649.29 .4 .611$

Patchin, J. W., \& Hinduja, S. (2010). Cyberbullying and self esteem. Journal of School Health, 80(12), 614-
621. doi: $\underline{10.1111 / j .1746-}$ 1561.2010.00548.x

Peplau, L. A., Micell, M., \& Morasch, B. (1982). Loneliness and selfevaluation. In Perlman, D., \& Peplau, L. A. (Eds). Loneliness, a sourcebook of current theory, research and therapy (pp. 135-151). A WileyInterscience Publication : New York.

Reece, T. (2012). Cyberbullying 411: Myths and truths about bullying and technology. Current Health Teens, A Weekly Reader Publication.

Reginasari, A. (2017). Peran harga diri pada hubungan antara persepsi terhadap mediasi orang tua dan perundungansiber. (Tesis tidak dipublikasikan). Universitas Gadjah Mada, Yogyakarta.

Rice, F. P., \& Dolgin, K. G. (2008). The adolescent development, relationship, and culture (Edisi kelima). USA: Pearson Publication.

Santrock, J. W. (2003). Adolescence (Edisi keenam). Diterjemahkan oleh Shinto B. Adelar dan Sherly Saragih. Jakarta : Erlangga.

Santrock, J. W. (2012). Life-span development (Edisi keempat belas). Diterjemahkan oleh Benedictine Widyasinta. McGraw-Hill International Edition.

Sari, S. V. (2015). Was it just joke? Cyberbullying perpetrations and their styles of humor. Computers in Human Behavior, 54, 555-569. doi: 10.1016/j.chb.2015.08.053

Sengupta, A., \& Chaudhuri, A. (2011). Are social networking sites a source of online harassment for teens? Evidence from survey data. Children and Youth Services Review, 33(2), 284290. doi: 10.1016/j.childyouth.2010.09.011

Sippola, L. K., \& Bukowski, W. M. (1999). Self, other, and loneliness from a developmental perspective. Dalam 
Rottenberg, K. J. \& Hymel, S. (Eds.). Loneliness in childhood and adolescent (pp. 280-295). Australia : Cambrige University Press.

Smith, P. K., Mahdavi, J., Carvalho, M., Fisher, S., Russell, S, \& Tippett, N. (2008). Cyberbullying: Its nature and impact in secondary school pupils. Journal of Child Psychology and Psychiatri, 49(4), 376-385. doi: 10.1111/j.1469-7610.2007.01846.x

Sticca, F. \& Perren, S. (2012). Is cyberbullying worse than traditional bullying? examining the differential roles of medium, publicity, and anonimity for the perceived severity of bullying. Journal of Youth Adolescence, 42(5), 739-750. doi: 10.1007/s10964-012-9867-3

Sticca, F., Ruggieri, S., Alsaker, F., \& Perren, S. (2013). Longitudinal risk factors for cyberbullying in adolescence. Journal of Community and Social Psychology, 23(1), 52-67. doi: $10.1002 /$ casp. 2136

Steinberg, L. (2011). Adolescence (Edisi kesembilan). New York: McGrawHill International Edition.

Suler, J. (2004). The online disinhibition effect. Cyberpsychology \& Behavior, 7(3), 321-326. doi: $\underline{10.1089 / 1094931041291295}$

Uba, I., Yaacoob, S. N., Juhari, R., \& Talib, M. A. (2010). Effect of self-esteem on the relationship between depresion and bullying among teenagers in Malaysia. Asian Social Science, 6(12), 77-85. doi: 10.5539/ass.v6n12p77

Vanhalst, J., Luyckx, K., Scholte, R. H. J., Engels, R. C. M. E., \& Goosssens, L. (2013). Low self-esteem as a risk factor for loneliness in adolescence: Perceived - but not actual - social acceptance as an underlaying mechanism. Journal of Abnormal Child Psychology, 41(7), 1067-1081. doi: 10.1007/s10802-013-9751-y

Valkenburg, P. M., \& Peter, J. (2011). Online communication among adolescent: an intergrated model of its attraction, opportunities and risks. Journal of Adolescent Health, 48(2), 121-127. doi: 10.1016/j.jadohealth.2010.08.020

Walrave, M., \& Heirman, W. (2011). Cyberbullying: Predicting victimisation and perpetration. Children and Society, 25(1), 59-72. doi: 10.1111/j.1099-0860.2009.00260.x

Weber, N. L., \& Pelfrey, W. V. (2014). Cyberbullying: Causes, consequences, and coping strategies. LFB Scholarly Publishing LCC : USA.

William, K. R., \& Guerra, N. G. (2007). Prevalence and predictors of internet bullying. Journal of Adolescent Health, 41, 516-521. doi: 10.1016.j.jadohealth.2007.08.018

Ybarra, M., Boyd, D., Korchmaros, J., \& Oppenheim, J. (2012). Defining and measuring cyberbullying within the larger context of bullying victimization. Journal of Adolescent Health, 51(1), 53-58. doi: 10.1016/j.jadohealth.2011.12.031

Ybarra, M. L., \& Mitchell, K. J. (2004). Online aggressor/targets, aggressors, and targets: a comparison of associated youth characteristics. Journal of Child Psychology and Psychiatry, 45(7), 1308-1316. doi: 10.1111/j.1469-7610.2004.00328.x

Yuliawanti, R. (2017). Eksplorasi cyberbullying dalam kaitannya dengan empati dan kualitas pertemanan remaja. (Tesis tidak dipublikasikan). Universitas Gadjah Mada, Yogyakarta. 